\title{
Özdeşlik İllkesi Sorunu ve Yansımalı Olmayan Mantıklar
}

\section{Problem of Identity Principle and Non-Reflexive Logics}

\author{
Halise Tarımcıoğlu ${ }^{1}$
}

'Doktora Öğrencisi, İstanbul Üniversitesi, Edebiyat Fakültesi, Felsefe Bölümü, İstanbul, Türkiye

ORCID: H.T. 0000-0002-7370-4303

Sorumlu yazar/Corresponding author: Halise Tarımcıoğlu,

İstanbul Üniversitesi, Edebiyat Fakültesi, Felsefe Bölümü, İstanbul, Türkiye

E-mail/E-posta: haliseavsar92@gmail.com

Başvuru/Submitted: 27.10.2019

Kabul/Accepted: 25.11.2019

\section{Atıf/Citation:}

Tarımcıoglu, Halise. (2019). "Özdeşlik ilkesi sorunu ve yansımalı olmayan mantıklar" Felsefe Arkivi- Archives of Philosophy, 51: 249260. https://doi.org/10.26650/arcp2019-5117

\section{ÖZET}

Özdeşlik ilkesi klasik mantığın dayanmış olduğu aklın üç temel ilkesinden biridir. Aklın diğer iki temel ilkesi ise çelişmezlik ve üçüncü halin imkansızlığıdır. Söz konusu ilkeler yirminci yüzyılın başlarına kadar neredeyse sorgusuz bir şekilde kabul görmüş ve dolayısıyla bu ilkelere bağlı kalarak çalışan klasik mantık da hüküm sürmeye devam etmiştir. Ancak günümüzde, bilim alanındaki en ilginç tartışmalardan biri, klasik mantığın dayanmış olduğu bu temel ilkelerin zorunlu ve değişmez doğruluklar olarak görülüp görülmeyeceğidir. Bu tartışmayla birlikte yirminci yüzyılda aklın temel ilkelerini reddeden mantıklar ortaya çıkmıştır. Bu çalışmada klasik mantığın diğer iki ilkesinin de kendisinden türetildiği özdeşlik ilkesini reddeden veya sınırlandıran mantıkları -yansımalı olmayan mantıkları- inceleyeceğiz. Öncelikle yansımalı olmayan mantıkların kökenlerinden bahsedeceğiz. Ardından klasik mantığın özdeşlik ilkesinin hangi temel varsayımlara dayandığı ele alınacaktır. Son olarak yansımalı olmayan mantıkların hangi gerekçelerle özdeşlik ilkesini reddettiği veya sınırlandırdığı, başka bir deyişle, özdeşlik ilkesinin hangi varsayımlarından dolayı sorunlu görüldüğü ele alınacaktır.

Anahtar Kelimeler: Özdeşlik ilkesi, yansımalı olmayan mantıklar, ayırt edilemezlik, tekillik

\section{ABSTRACT}

The principle of identity is one of the three basic principles of reason on which classical logic rests. The other two basic principles of reason are principle of noncontradiction and of the excluded middle. These principles were accepted almost unquestionably until the beginning of the twentieth century. Therefore, classical logic, which adhered to these principles, continued to prevail. Today, however, one of the most interesting debates in the field of science is whether these fundamental principles on which classical logic rests can be seen as necessary and invariable truths. With this discussion, a logic emerged in the twentieth century, rejecting the basic principles of reason. In this study, we will examine the logics -non-reflexive logics- that rejects or limits the principle of identity, from which the other two principles of classical logic are derived. First of all, we will talk about the origins of non-reflexive logic. Next, the basic assumptions of the identity principle of classical logic will be discussed. Finally, we will discuss the reasons for which non-reflexive logic rejects or limits the principle of identity, in other words, which assumptions of the identity principle are considered problematic.

Keywords: Identity principle, non-reflexive logics, indiscernibility, individuality 


\section{Giriş}

Yirminci yüzyıl birçok alanda önemli gelişmelerin olduğu bir dönemdir. Bu gelişmelerle birlikte söz konusu bilimler hakkındaki bilgilerimiz değiştiği gibi bu bilgiler ışığında genel olarak ontoloji ve epistemoloji anlayışları üzerinde de önemli değişiklikler olmuştur.

Klasik olmayan mantıkların ortaya çıkmasındaki büyük etken de önemli ölçüde mantık, matematik ve fizik gibi alanlarda meydana gelen gelişmelerdir. Bu gelişmelerin temel amaçlarından biri ise var olan paradokslara çözüm üretmektir. Dolayısıyla klasik mantık sınırları içerisinde kalarak çözülemeyen paradoksların yeni mantık anlayışları ışığında çözülebileceği düşüncesi yeni mantık çeşitlerini doğurmuştur. Bir başka açıdan bakıldığında, klasik olmayan mantıklara neden ihtiyaç duyulduğuna yönelik iki muhtemel yanıt verilir. Bunlardan ilki, klasik mantığın bir model olarak formel mantığı doğrulamada yetersiz görülmesidir, ikincisi ise zamansal bağımlılıklara veya bilgi, inanç ve doğru ayrımına ilişkin yetersiz ifade edilebilirliğe sahip olarak görülmesidir. ${ }^{1}$ Dikkat edilirse genel olarak klasik olmayan mantıkların en temelde klasik mantığın eksiklerini gidermek için geliştirildikleri anlaşılmaktadır.

Klasik olmayan mantıkların birçoğu 20. yüzyılın başında ortaya çıkmaya başlamış, aklın temel ilkelerinden en az birini reddederek veya bu ilkeleri kabul ederek geliştirilmiş mantıklardır. Bu bakımdan klasik olmayan mantıkları ortaya çıkış sebepleri bakımından ikiye ayırmak mümkündür. Susan Haack'e göre klasik olmayan mantıklardan klasik mantığın dayanmış olduğu ilke ve yasaları reddetmeden, klasik mantığa yalnızca yeni mantıksal operatörler ekleyerek klasik mantığı genişleten mantıklara genişletilmiş mantıklar, klasik mantığın temel yasa ve ilkelerinden en az birini reddederek kendini tanımlayan mantık çeşitlerine sapkın mantıklar denir. ${ }^{2}$ Pek çok düşünür Susan Haack'in sapkın ve genişletilmiş mantık ayrımını kabul etmiş olsa da John P. Burgess benzer bir ayrıma giderek bu iki tür mantık sınıfını anti-klasik ve $\boldsymbol{e k s t r a - k l a s i k}$ olacak şekilde adlandırır. ${ }^{3}$

Çalışmamızın devamında, klasik mantığın en az bir ilkesini reddetmeleri nedeniyle, ortaya çıkış sebeplerine de daha uygun olduğunu düşündüğümüz Susan Hack'in sapkın mantıklar ifadesini kullanmayı tercih ettik.

Klasik olmayan mantıklardan klasik mantığın uzantısı olanların, yani genişletilmiş mantıkların iddiası, klasik mantığın yeterli olmadığı, başka operatörlere ihtiyaç duyulduğu, değişik modalitelerin olması gerektiği ve önermelerin bu modaliteler açısından da incelenmesi gerektiğidir. Bu mantıklar klasik mantığın dayandığı aklın temel ilkelerinden herhangi birini reddetmezler, aksine klasik mantığın bir devamı veya uzantısı niteliğindedirler; dolayısıyla bir karşı duruş sergilemezler. Bu mantıkların en temel iddiası dünyadaki mantıksal nitelemelerin tüketilebilir olmadığı düşüncesidir.

1 Chris Fermüller, "Nonclassical logics”, 2016/2017, s.4-5.

2 Susan Haack, Deviant logic: some philosophical issues, Cambridge University Press, London, 1974, s.4. Aslında Susan Haack aynı kitapta (Deviant Logic, 1974) klasik olmayan mantıkları üç sınıfa ayırır; sapkın, yarı-sapkın ve genişletilmiş mantıklar. Yarı-sapkın mantıklar hem yeni oluşturulmuş iyi teoremleri hem de klasik mantık sınırları içerisinde oluşturulmuş iyi teoremleri kullanarak yeni teoremler oluşturan mantıklardır. 
Klasik olmayan mantıklardan klasik mantığın temel ilkelerinden en az birini reddedenlerin, yani sapkın olanların iddiası ise klasik mantığın yetersiz olmasını dayanmış olduğu ilkelerle açıklarlar. Sapkın mantıklardan en çok dikkat çekenleri aklın üç temel ilkesinden en az birini reddeden mantık sistemleridir. Daha önceleri klasik mantığın tartışılmaz bir ilkesi olarak kabul edilenin, uygun bir mantığın tanıtımı ışığında zamanla gözden geçirilip değiştirilmeye açık olduğu ortaya çıkmıştır. "Söz gelimi ara değerlerin dışlanması veya üçüncü halin imkansızlığı klasik mantıkta temel bir ilkedir ancak görüselci veya çok değerli mantıklarda genellikle geçerli değildir. Çelişmezlik ilkesi de klasik mantığın diğer temel ilkelerinden biridir, ancak o da tutarlılık üstü (paraconsistent] mantıkta geçerli değildir. Diğer iki ilkenin de kendisinden türetildiği özdeşlik ilkesi ise yansımalı olmayan mantıklar [Non-reflexive Logics] tarafından zorlanmaktadır.”

Bu çalışmada incelenecek olan sapkın mantık çeşidi, klasik mantığın özdeşlik ilkesini sınırlandıran veya reddeden Yansımalı Olmayan Mantıklardır. Çalışmanın devamında Yansımalı Olmayan Mantıkların nereden neşet ettikleri, temel iddialarının neler olduğu ve özdeşlik ilkesini dolayısıyla da klasik mantığı hangi bakımlardan eleştirdiği incelenecektir.

\title{
A.Yansımalı Olmayan Mantıkların Kökeni
}

Yansımalı olmayan mantıkların öncüsü Newton C. A. da Costa'ır. Da Costa teorinin kurucu babalarından olan E. Schrödinger'in mantığını formelleştirerek ona Yansımalı Olmayan Mantıklar adını verdi. E. Schrödinger'e göre özdeşliğin bazı durumlarda kuantum parçacıkları için hiçbir anlamı yoktur. Schrödinger'in kuantum varlıkların özdeşliği hakkındaki en bilinen ifadeleri şunlardır:

\begin{abstract}
... 'aynılık'ın tamamen anlamsız hale geldiği başka durumlar vardır; ve onların arasında keskin bir sınır yoktur, kesin bir ayrım yoktur, ara durumlar üzerinde kademeli geçiş vardır. Bunu vurgulamak için ve ona inanmanız için size yalvarıyorum: Bazı durumlarda özdeşliği belirleyemememiz ve diğerlerinde de yapamamamız söz konusu değildir. Kuşkusuz ki, 'aynılık’n, özdeşlik’in, gerçekten ve gerçekten hiçbir anlamı yoktur. (Schrödinger) ${ }^{5}$
\end{abstract}

Yukarıdaki alıntıda Schrödinger'in özdeşliği atfetmenin anlamsız olduğunu söylediği durumlar kuantum mekaniğindeki parçacıkların durumlarıyla ilgilidir. Schrödinger'e göre atomları, en azından sürekli olarak takip edebileceğimiz, iyi tanımlanmış bir yörüngeye sahip sürekli nesneler olarak alan geleneksel anlayış, kuantum mekaniğinde tamamen terk edilmelidir. ${ }^{6}$ Schrödinger'in özdeşlik ilkesine yapmış olduğu bu eleştirilerin formelleştirilmeye çalışılmasıyla geliştirilen Yansımalı Olmayan Mantık sistemleri, daha sonraları Décio Krause tarafından daha üst derece sistemlere çıkarıldı ve buradan yarı-küme teorisi (quasi-set theory) geliştirildi.

4 Newton C. A. Da Costa, Otavio Bueno, Lodicas nao-reflexivas, 2009, s.182.

5 Akt: Newton C. A. Da Costa and Décio Krause, An Intensional Scrödinger Logic, Notre Dame Journal of Formal Logic Volume 38, Number 2, Spring 1997, s.180.

6 Jonas R. Becker Arenhart, Newton da Costa On Non-Reflexive Logics and Identity, Brazil, s.5.

7 Yarı-küme teorisi, temelde kuantum fiziğinde ele alınan bazı nesnelerin ayırt edilemez oldukları ve bireyselliklerinin/ tekilliklerinin olmadığı varsayımıyla motive edilmiş olan, ayırt edilemez nesnelerin toplamlarıyla ilgilenen formel bir matematiksel teoridir. Décio Krause tarafından reflektif olmayan mantıklardan geliştiriliyor. 
Görüldüğü üzere yansımalı olmayan mantıkların ortaya çıkması fiziğin temelleriyle ilgili tartışmalardan kaynaklanmaktadır. Bu sistemleri geliştirmek için gerekli olan ana motivasyon göreceli olmayan kuantum mekaniğinden (non-relativistic quantum) gelmektedir. ${ }^{8}$ Göreceli olmayan kuantum mekaniğine göre "kuantum varlıkların bir şekilde "özdeşliklerini kaybettikleri”, tekil olmayan [non-individual] oldukları iddia edilir."9 Bunun nedeni kuantum parçacıkları arasında dolanık bir ilişki olmasıdır. Dolanıklık (entanglement) genel olarak şöyle açıklanabilir:

Dolanıklık en az iki nesneyi içeren bir sistemin kuantum durumunun bir özelliğidir, bu iki nesne ki, sistemin herhangi bir üyesinin durumunu [hızını ve konumunu] diğer üyesinin durumlarından bahsetmeden yeteri kadar tanımlayamadığımız şekilde birbirine bağlı olan iki nesnedir. Ve bu, nesneler birbirinden uzakta olsalar bile böyledir. ${ }^{10}$

Alıntı uyarınca parçacıklar arasındaki dolanıklık ilişkisi, aynı anda sürekli bir etkileşimi ve geçişi, dolayısıyla da değişimi ifade eder. Dolanıklık söz konusu olunca bir parçacık hakkında konuşmak sistemdeki her parçacık hakkında bilgi sahibi olmayı gerektirir. Sözgelimi normal şartlarda bildiğimiz şekliyle yazılmış 100 sayfalık bir kitabın ilk 10 sayfasını okuduğumuz zaman kitabın yüzde 10'u hakkında bilgi sahibi olduğumuzu düşünürüz, ancak aynı kitap kuantum dünyasına göre yazılırsa ve ilk on sayfasını okursak, bu tür bir kitapta bilgi her sayfaya birbirinden bağımsız bir şekilde yazılmadığı için ve bilgi sayfalar arasındaki ilişkilerin veya bağlantıların içerisine gömülü olduğu için, kitabın tamamını okumadığımız sürece kitap hakkında hemen hemen hiçbir şey öğrenemediğimiz anlayışı hakimdir. ${ }^{11}$ Dolayısıyla kuantum parçacıkları arasında dolanıklıktan kaynaklanan sürekli bir geçiş ve etkileşim söz konusuyken klasik mantığın özdeşlik ilkesinin ifade ettiği keskin ayrımın kuantum evreninde de geçerli olduğunu söylemek mümkün değildir. Burada A gibi bir parçacık hem A'dır hem de A olmayandır. Dolayısıyla yansımalı özdeşlik ilkesinin ihlali söz konusudur.

En genel haliyle özdeşlik, yansımalı özdeşlik ilkesi ve yansımalı olmayan mantıkları tanımlamak gerekirse şöyle söylemek mümkündür:

“Özdeşlik İlkesi (ÖI): Her nesne kendisine özdeştir.

Yansımalı Özdeşlik Illkesi $(Y \ddot{O} \dot{I}): \forall x(x=x)$

Yansımalı Olmayan Mantıklar (YOM): Yansımalı özdeşlik yasasının sınırlandırıldı̆̆ı veya geçerli olmadı̆̆ı mantıklar.

8 Jonas R. Becker Arenhart, New logics for quantum non-individuals?, s.1., Ayrica bkz: Jonas R. Becker Arenhart, Newton da Costa On Non-Reflexive Logics and Identity, s.2.

9 Jonas R. Becker Arenhart, Newton da Costa On Non-Reflexive Logics and Identity, s.1.

10 Décio Krause, The Problem of Identity and a Justification for Non-Reflexive Quantum Mechanics, 2011, s.2. Detaylı bilgi için Bkz: Şevki Işıklı, Kuantum Felsefesi Postmodern Bilimin Doğuşu, Ankara, Birleşik Yay., 2012, s. 110 .

11 Bkz: John Preskill, Quantum Computing and The Entanglement Frontier, Rapporteur talk at the 25th Solvay Conference on Physics “The Theory of the Quantum World” Brussels, 19-22 October 2011, s.2-3. 


\section{Yansımalı özdeşlik ilkesinin olumsuzlanmast: $\exists x(x \text { eşit değildir } x)^{12}$}

Dikkat edilirse ilk adımda özdeşlik ilkesi formel olmayan bir dille ifade edilmiştir. Oysa ikinci adımda ilk ilke formel dile uygun şekilde ifade edilmiştir. Genellikle ikinci ilkenin ilkini şekillendirdiği söylenir, daha doğrusu ikincisi birincinin formel karşılĭgıdır.13 Arenhart ve da Costa'ya göre yansımalı olmayan mantıklar ise ikinci ilkeye bir sınırlama getirmektedir; bu sınırlama, özdeşlik ilkesinin bu tür sistemlerde başarısız olduğu anlamına gelir.

Yukarıda verilmiş olan ilkelerden ilk olarak biri diğerinin formel dilde ifade edilmiş hali olan ve klasik mantığın temel aldığı ilk iki ilkeyi ele alalım. Öncelikle sorulması gereken soru şudur: Özdeşlik ilkesinden ne anlaşılmaktadır, hangi temel varsayımlara dayanmaktadır veya hangi temel varsayımları içermektedir? İzleyen bölümde bu temel varsayımları detaylandıracağız.

\section{Klasik Mantığın Özdeşlik Anlayışı}

Klasik mantık uğraştığı her varlığın bir özdeşliğe sahip olduğunu var sayar. Klasik mantığa göre $x$ ve y gibi herhangi iki nesne bizim için ya özdeş ya da farklıdırlar. Bu bakımdan "standart özdeşlik teorisi iki farklı nesnenin, en azından ilkece, nitelikleri bakımından aralarında bir fark olduğunu söyler”. ${ }^{14}$ Eş deyişle tek bir şey olmak veya tekil olmak bakımından tekilliğe, dolayısıyla da özdeşliğe, sahip olan şeyler diğer şeylerden her zaman farklıdır. Bazen bir şeyin, aradaki farkın ne olduğunu söyleyemeyecek kadar başka şeylerle ortak yanları olsa bile o şeyin o şey olduğunu, kendisinden başka bir şey olmadığını varsayma eğilimindeyizdir. Ĕger onların ikisine sahipsek, onlar zaten iki şey olmak bakımından farklıdırlar. Bununla birlikte yine de biz ikisi arasındaki ayırt edici özelliği belirtemeyebiliriz. Yine de tüm özellikleri aynı olsa bile iki şey arasında ayırt edici özellik olarak karşımızda duran şey, söz konusu iki şeye tekillik veren mekân ve zamandır. Şöyle ki, normal şartlarda (makro dünyada) her şey belli bir mekânda ve belli bir zamanda olmak bakımından diğer şeylerden ayırt edilebilirdir. Yalnızca bu varsayımdan dolayı bile özdeşlik, klasik mantıktaki her varlık için tamamen anlamlıdır. ${ }^{15} \mathrm{Bu}$ nedenle özdeşlik ilkesi felsefi gelenekte mantığın temel ilkelerinden biri ve daha genelde çelişmezlik ve üçüncü halin olanaksızlığıyla birlikte düşünmenin temel ilkelerinden biri olarak dikkate alınır. Hatta Ruth Barcan Marcus’a göre “özdeşlik geçişli, yansımalı ve simetrik olan en güçlü denklik băğntısıdır." ${ }^{16}$ Bu çalışmada özdeşliğin ele alınacak yanı yansımalı olma özelliğidir.

French ve Krause'ye göre klasik mantık, özdeşlik ilkesini kabul ederek bize tamamen ayırt edilebilirlik ve bir tekiller teorisi taahhüt eder. ${ }^{17}$ Bu konuda Arenhart şunları söyler:

12 Decio Krause, Quantum Mechanics, Ontology, and Non-Reflexive Logics, 2018, s.16.

13 Jonas R. Becker Arenhart, Newton da Costa On Non-Reflexive Logics and Identity, s.2.

14 Decio Krause, Quantum Mechanics, Ontology, and Non-Reflexive Logics, s. 13.

15 Jonas R. Becker Arenhart ve Décio Krause, Classical logic or non-reflexive logic? A case of semantic underdetermination, Publicado na Revista Portuguesa de Filosofia 68, 2012, s.74.

16 Akt: Jean-Yves Beziau, What is the principle of identity?, Logica e Flosofia da Logica, 2004, s.1. bkz:

17 Jonas R. Becker Arenhart, New logics for quantum non-individuals?, s.6. 
French ve Krause, klasik mantığın "doğru bir şekilde ayırt edilemeyen ve dolayısıyla tekil olmayan" varlıkları ele almaktan onu alıkoyan bir özdeşlik teorisi içerdiğini iddia ederler. Burada klasik mantığın yeterliliği bakımından zorlukların iki kaynağı olduğu iddia edilir: i) o, tekillerle uğraşır ve ii) o, ayırt edilebilir nesnelerle uğraşır. Öte yandan yansımalı olmayan mantıklar, ayırt edilemeyen ve tekil olmayan varlıkları hesaba katarak her iki probleme de çözümler sağlamaya çalışır.

Klasik küme teorisiyle olan problemin, standart matematik dilinin, bir kümenin ayırt edilebilir nesneler toplamı olduğu varsayımına dayanması olduğu iddia edilir (French and Krause). Öyleyse, bu anlamda, yeni sistemde değiştirilmesi gereken şey, klasik küme teorisindeki her öğenin diğer her öğeden ayırt edilmiş olabilmesi gerçeğidir. Buradaki problem ayırt edilebilirliktir: her öğe, onun, küme teorisindeki diğer her parçadan ayırt edilmesini sağlayan bir özelliğe sahiptir. ${ }^{18}$

Alıntıdan da açıkça anlaşıldığı üzere klasik mantık birçok versiyonunda (birinci derece, ikinci ve daha yüksek derece ve küme teorisinde), yansımalı olmayan mantıkların ortaya çıkma sebebi olan kuantum varlıkların iki temel özelliğinin doğrudan ihlallerini içerir. Dikkat edilirse klasik mantığın ayırt edilebilir nesnelerle ve tekillerle ilgilendiği açıktır. Görmüş olduğumuz üzere French ve Krause ayırt edilemezlik ve tekillikten farklı şeyi anlarlar: "Ayırt edilemezlikten, ilgili türdeki her özelliğin paylaşılması şeklinde anlaşılırken, tekillik biçimsel açıdan öz-kimlik/öz-özdeşlik [self-identity] tarafindan temsil edilen bir özgünlüğe sahip olmak şseklinde anlaşılır. Dolayısıyla, iki problemin çözümü iki aşamada să̆lanmalıdır: yeni bir ayırt edilemezlik bă̆ıntısı ve özdeşliğin düşü̧ü olmalıdır.” 19

Dikkat edilecek olursa kuantum mekaniğinde klasik mantığın özdeşlik anlayışında olduğu gibi nesneler belli bir mekâna sahip değildirler, aynı anda iki parçacığın aynı yerde olması mümkün. Dolayısıyla özdeşlik ilkesi gereği bir şeyi diğerinden ayırt etmenin biricik yollarından biri olan "belli bir mekânda olma" durumu artık ayırt edilebilir bir durum değildir. Bu durumda kuantum parçacıkların ayırt edilemez oldukları sonucuna varılır. Ayırt edilemez varlıklar ise belli bir tekilliği olmayan varlıklar olarak klasik mantık açısından tasviri mümkün olmayan varlıklardır. Dolayısıyla normalde makro dünyada bir şeyin özdeşliğinin bir tekilliğe (bir mekânda ve zamanda olması) sahip olmak üzerinden tanımlanması geçerliyken, bu tanım kuantum alemindeki parçacıklar için geçersizdir.

Kuantum varlıkların ayırt edilemez olmaları ve tekil olmamaları nedeniyle çok farklı bir metafizik doğaya sahip olduğu söylenir; bu ayırt edilemezlik ve tekil olmayış, yansımalı olmayan mantık sistemlerinin bazı savunucularına göre kuantum varlıkların özdeşlikten yoksun olmalarıyla açıklanmaktadır. Dolayısıyla "klasik mantık sadece tekillerle ilgilendiğinden, tekil olmayan bir metafizik varsaymak zorundaysak o halde klasik mantık yansımalı olmayan sistemlerle yer değiştirmek zorundadır". ${ }^{20}$

18 A.e., s.3.

19 Jonas R. Becker Arenhart, New logics for quantum non-individuals?, s.20.

20 A.e., s.1. 
Anlaşılan o ki, kuantum mekaniğinin ayırt edilemeyen ve tekil olmayan varlıklarla ilgilendiğini ve ayırt edilememe ve tekil olmama özelliklerinin özdeşliğin yetersizliği üzerinden yorumlanması gerektiği varsayılacaksa, o zaman özdeşliği içeren klasik mantığın gözden geçirilip değiştirilmesi gerekir. French ve Krause klasik mantığın gözden geçirilmesi gereken tarafının klasik küme teorisi olduğunu ileri sürerek şunları söylerler:

Klasik küme teorisi ve mantık bir kümenin elemanlarını bir tür tekil olarak alan bir özdeşlik teorisi içerir. Kısacası bu "özdeşlik teorisi”, mutlak bir şekilde veya 'güçlü bir şekilde' ayırt edilemez varlıklar olarak kuantum varlıkların elde edilen görünümü ile çelişmektedir ve özdeşlik ilkesi ayırt edilemez tekil olmayan varlıkları 'doğru bir şekilde' ele almanın temellerini sağlayamaz. ${ }^{21}$

Klasik mantık ve klasik küme teorisi "ayırt edilemeyen ve tekil olmayan” varlıkları açıklamada yeteri kadar başarılı değildir. Bunun temel nedeni ise klasik mantığın bu tür varlıkları dikkate alan bir anlayışa sahip olmamasıdır. Başka bir deyişle bunun iki türlü nedeni vardır:

(i)klasik mantık tekil olmayanlarla uğraşamaz, çünkü o yalnızca tekillerle uğraşır,

(ii)klasik mantık ayırt edilemeyen varlıklarla uğraşamaz, çünkü o sadece ayırt edilebilir varlıklarla uğraşır.

Açıkça görülmektedir ki, klasik mantık, "ayırt edilemezlik" ve "tekil olmama” özelliğine sahip varlıkları doğru bir şekilde açıklamada başarısızdır. Bu nedenle ayırt edilemeyen ve "tekil olmayan varlıkları farklı bir tür mantık kullanarak tasarlamak gerekir ve bunun için doğal bir aday yansımalı olmayan olarak bilinen bir mantıklar sınıfıdır. Yansımalı olmayan mantıklar, bir şekilde klasik mantığın standart özdeşlik kavramının geçerliliğini ihlal eden veya sınırlandıran mantık sistemleridir”22. Özellikle, bazı yansımalı olmayan mantıklarda, özdeşliğin bazı varlık türleri arasında geçerli olmadığı görülmektedir. Şimdiye kadar söylenenlerden hareketle, özdeşliğin bütünüyle tanımlı bir bağıntı olmadığı kolaylıkla anlaşılır bir sonuçtur. Bunun temel sebebi ise klasik mantığın özdeşlik ilkesinin her şeyin tekil, ayırt edilebilir ve kendisine özdeş olduğu varsayımlarından yola çıkmasıdır. Öyleyse izleyen bölümde, yansımalı olmayan mantıkların klasik özdeşlik ilkesinin bu varsayımlarına karşılık hangi iddialarda bulunduğuna bakalım.

\section{II.Yansımalı Olmayan Mantıklar ve Özdeşlik İlkesi}

Yansımalı olmayan mantıkların öncüsü Newton C. A. da Costa’ya göre yansımalı olmayan mantık en geniş anlamda, özdeşlik bağıntısını sinırlandıran, ortadan kaldıran veya en azından daha zayıf bir bağıntı ile değışstiren veya yeni bir yansımalı olmayan çıkarım ile ve dengi bağıntıyla birlikte

21 Akt: Jonas R. Becker Arenhart, New logics for quantum non-individuals?, s.2.

22 Jonas R. Becker Arenhart ve Décio Krause, Classical logic or non-reflexive logic? A case of semantic underdetermination, s.74. Klasik mantığın dayandığı aklın temel ilkelerini reddetmenin veya sınırlandırmanın çeşitli yolları olduğu için, mantıksal çokluluk da bu yolla gerekçelendirilir. 
kullanan bir mantıktır." ${ }^{23} \mathrm{Bu}$ anlamda, yansımalı olmayan mantık sistemleriyle özdeşliğin genel olarak geçerli olduğu klasik mantığın gözden geçirilip değiştirilmesi amaçlanır. Bu amaçla da Costa özdeşlik ilkesini göz önünde tutarak yansımalı ve yansımalı olmayan şeklinde bir mantık sınıflaması yapar. Ona göre:

Bir taraftan (i)Yansımalı mantıklar vardır. Bunlar, klasik mantığın diliyle formüle edilebilen her bir özdeşlik ilkesinin versiyonunun geçerli olduğu mantıklardır. Öte yandan (ii) Yansımalı olmayan mantıklar vardır. Bunlar özdeşlik ilkesinin tamamen veya en azından kısmi şekilde ortadan kaldırıldığı mantıklardır. ${ }^{24}$

Yansımalı olmayan mantık sistemlerini geliştirmek için gerekli olan ana motivasyonun göreceli olmayan kuantum mekaniğinden geldiğini daha önce belirtmiştik. Kuantum mekaniği klasik mantığın terimleriyle uğraşılması güç olan birtakım ontolojik meseleler ortaya çıkarır. Mesela kuantum mekaniğindeki "parçacık" kavramı, formel bir bakış açısından analiz edildiğinde, ciddi zorluklarla karşılaşılır. Bu zorluklardan biri kuantum parçacıkların özdeşliği problemidir. $\mathrm{Bu}$, genellikle parçacıkların ayırt edilemezliği problemi olarak bilinir. Özellikle, kuantum parçacıkları göz önüne alındığında özdeşlik kavramının anlamsız olduğu veya en azından bazı bakımlardan sınırlandırılması veya değiştirilmesi gerektiği açıktır. Dolayısıyla kuantum mekaniğindeki gibi birini diğerinden ayırt edici bir özelliği olmayan, yani özdeşliği olmayan varlıkların, kendi başlarına, sağlam mantıksal bir değerlendirmesinin yapılabilmesi için, geleneksel özdeşlik yasalarının bazılarını ihlal eden bir mantık sisteminin kullanılması gerektiği ileri sürülmektedir. ${ }^{25} \mathrm{Da}$ Costa, özdeşlik ilkesinin tamamen geçerli olmadığını iddia eden yansımalı olmayan mantıklar kuantum parçacıkların ve onların özdeşliklerinin yorumunu dikkate almada zorluklar yaşayan kuantum mekaniği için faydalı bir araç olabileceğini düşünür. Yansımalı olmayan mantıklar ayrıca klasik özdeşliğin sınırlarının ötesini düşünmemize de yardımcı olur. ${ }^{26}$

Demek ki yansımalı olmayan mantıkları gerekçelendirme çabası, klasik olmayan türden bir mantığa dayanan kuantum mekaniği için alternatif bir yaklaşım arama çabasının bir sonucudur. Kuantum mekaniğindeki dolanıklık ve quantaların ayırt edilemezliği kuantum mekaniğinde klasik mantık kavramlarıyla açıklanamayan iki önemli sorun olarak karşımıza çıkmaktadır. ${ }^{27}$

Yansımalı olmayan mantığı daha üst seviyelere taşıyan ve klasik küme anlayışından farklı yeni bir küme teorisi (yarı-küme teorisi) geliştiren Décio Krause’ye göre özdeşlik belirli alanlarda kullanışlı bir kavramdır, ancak özellikle kuantum aleminde özdeşlik kavramı ayırt edilemezlik kavramı ile yer değiştirir. Bu varsayımdan hareketle Krause, kuantum mekaniğinin bir yorumunun, yansımalı olmayan şeklinde adlandırılan, klasik olmayan bir mantığa dayandığını

23 Newton C. A. da Costa and C. de Ronde, Non-Reflexive Logical Foundation for Quantum Mechanics, in Foundations of Physics, December 2014, s.2.

24 Newton C. A. Da Costa, Otavio Bueno, Lodicas nao-reflexivas, 2009, s.184.

25 Jonas R. Becker Arenhart ve Décio Krause, Classical logic or non-reflexive logic? A case of semantic underdetermination, s.74.

26 Newton C. A. da Costa and C. de Ronde, Non-Reflexive Logical Foundation for Quantum Mechanics, in Foundations of Physics, s.1.

27 Décio Krause, The Problem of Identity and a Justification for Non-Reflexive Quantum Mechanics, s.1. 
düşünür ve ona göre böyle bir mantığa karşılık gelen mekaniklere de yansımalı olmayan kuantum mekaniği denir. ${ }^{28}$

Bilindiği üzere kuantum mekaniğinde aynı tür kuantum varlıklar, genellikle ayırt edilemez olarak dikkate alınırlar. Eş deyişle kuantum varlıkları ayırt edebilecek hiçbir özellik yoktur. Dolayısıyla ayırt edilemeyen varlıkların uygun bir şekilde ifade edilebileceği bir mantık gereksinimi ortaya çıkar. Bu gereksinim French ve Krause tarafından şöyle dile getirilir:

Aynı tür temel kuantum varlıklar ayırt edilemez olabilirler ve bu yüzden onların uyacağı bir 'mantık' türü aramak için uygun bir sorundur. Elbette, böyle bir mantıkta, biz ayırt edilemezlikten konuşabileceğiz ve Leibniz Yasası’nın ima ettiği gibi, bazı varlıkların tamamen aynı varlık olarak meydana gelmeksizin ortaklaşa tüm ilgili özelliklere sahip olabileceklerini düşünebileceğiz. ${ }^{29}$

Alıntıda geçen Leibniz Yasası ile kast edilen Ayırt Edilemezlerin Özdeşliği İlkesidir. Bu ilkeye göre sayıca farklı varlıklar, en azından bir özellik bakımından ayırt edilebilir olmalıdır. Aksi halde söz konusu varlıkların sayıca farklı olmaları da mümkün olmazdı. Sayıca farklı varlıklar olmalarına rağmen, kuantum varlıkların niteliksel açıdan ayırt edilemez durumlarının olması ayırt edilemezlerin özdeşliği ilkesini açıkça zayıflatır. Yansımalı olmayan mantıklar tam olarak bu ayırt edilemezlik bağıntısıyla ilgilenir. Bu bağıntıya göre öğeler aynı olmaksızın ayırt edilemez olabilir, dolayısıyla da ayırt edilemezlerin özdeşliği ilkesi ihlal edilmiş olur.

Ayırt edilemez öğelerin özdeş olduğunu kabul eden ilkeye göre metafizik açıdan, tekil olan bir şey taşıdığı özelliklerin ne daha azı ne de daha fazlası olamaz. Başka deyişle tekil, onu tekilleştiren özelliklerin demet kuramlarıyla ilgilidir. Dolayısıyla tekiller arasındaki sayısal fark, bu tekilleri oluşturan demetlerdeki farklarla açıklanır. Başka bir deyişle söz konusu demetler, tekilliklere kanıt olarak gösterilen özelliklerdeki farkı açıklar. Tekil olmanın veya olmamanın ayırt edilemezlik'le olan bağıntısını Arenhart şu şekilde ifade eder:

Kuantum varlıkların ayırt edilemezlerin özdeşliği ilkesini başarısız kıldığı göz önüne alınırsa, bu yasayı başarısız kılan varlıkların bir tür tekil olmayan olarak görülebileceği varsayılabilir. Bu anlamda, ayırt edilemezlik ve tekil olmama problemleri aynı türden bir çözüme sahip olacaktır: tekil olmayan varlıklar, başka aynı tür varlıklara özdeş olmaksızın ayırt edilemeyen varlıklardır. Dolayısıyla French ve Krause'ye göre "klasik diller özellikle tekillerden konuşur”. Bu anlamda problem tekilliktir. ${ }^{30}$

Kuantum varlıkları dikkate aldığımız zaman gerçekten de ayırt edici özellikleri fark edilemeyen varlıkların olduğu gözlenmektedir. Normalde ayırt edilemeyen nesneler hiçbir şekilde bir fark göstermezler, tüm özellikleri paylaşırlar. Bu şekilde ayırt edilemeyen nesneler klasik anlayışta özdeş nesneler olarak, yani aynı, farklı olmayan nesneler olarak kabul edilirler. "Dolayısıyla a’nın $b$ ile aynı olduğunu söylemek (sembol olarak $a=b$ ), a ile b'nin iki ayrı parça olmadiğı, onun yerine

28 A.e., s.2.

29 Akt: Jonas R. Becker Arenhart, New logics for quantum non-individuals?, s.4.

30 A.e., s.4. 
yalnızca birinin hem a'ya hem de b'ye atıfta bulunabildiğgi’31 anlamına gelir. Bir başka deyişle aynı/ özdeş olmak bakımından bir'dirler. Dolayısıyla klasik anlayışa göre birbirinden hiçbir şekilde ayırt edilemeyen bir ikilikten, iki ayrı nesneden söz etmek mümkün değildir. Ayırt edilemiyorsa bir özdeşlik, yani birlik söz konusudur. Ancak kuantum mekaniğinde iki varlık olduğu halde ayırt edilemeyen, tüm özellikleri paylaşan varlıkların gözlenmesi, ayırt edilemezlik ve özdeşlik kavramlarının yeniden gözlen geçirilmesi gerektiğinin kanıtıdır. Décio Krause ayırt edilemezlik ile özdeşlik kavramı arasında bir ayrım yaparak kuantum varlıklar için bir anlam ifade edenin ayırt edilemezlik kavramı olduğunu iddia eder:

[Ayırt edici özellikleri fark edilemeyen varlıklar vardır]. Bu tür varlıkları ele almanın en iyi yolu standart özdeşlik teorisinde ortaya çıkan iki kavramı ayırmaktır: ayırt edilemezlik ve özdeşlik. Ayırt edilemez nesneler özellikler paylaşır. [...] Özdeş nesneler ise farklı nesneler değillerdir, aksine aynı birdirler. Diğer bir deyişle bir nesneden daha fazlası yoktur. Bana göre ilk kavram kuantum mekaniğinde kullanışlıdır, oysa ikincisi sorunlara sebep olur ve belki de sadece matematik, sanat ve insan ilişkilerinde kullanışlıdır. ${ }^{32}$

Alıntıda da açıkça ifade edildiği üzere Krause özdeşlik ve ayırt edilemezlik arasındaki ayrıma açıklık getirdikten sonra, kuantum varlıklar açısından asıl önemli mesele tekillik olduğu için, tekil olmanın ayırt edilebilirlikle ilgili bir sorun olmadığını, aksine daha çok özdeşlikle ilgili bir sorun olduğunu ileri sürer: "Yansımalı özdeşlik ilkesi, $\forall x(x=x)$, genellikle geçerli olmadiğı için, biz tekil olmama kavramının öz-kimliğin/öz-özdeşliğin her zaman iyi tanımlanmadı̆̆ı sistemler yoluyla kuantum bağlamında yakalanabileceği iddiasını savunacă̆gz."33 Arenhart dolayısıla, tekil olmamanın [non-individuality] da ayırt edilemezlikle değil, aksine daha çok öz-kimlikten/ özdeşlikten eksik olmakla ilgili olduğunu söyler. Arenhart’a göre burada önemli olan şey “özgünlüğ̈̈n [haecceity], belirli özelliklerin somutlaştırdiğg niteliksel özelliklerden băğmsız bir şekilde tekilliği sağlayan bir tür tekilleştirme mekanizması olmasıdır. Bu anlamda iki parçacık, her niteliksel özelliği pek ala paylaşabilir ve farklı özgünlükler taşıdıkları için, hala sayısal olarak farklı olabilirler"34. Öyleyse “tekiller, öz-kimliklözdeşlik tarafindan temsil edilen bir özgünlüğe sahiptir, oysa tekil olmayanlar özdeşliğin onlar için hiçbir anlam ifade etmemesi nedeniyle hiçbir özgünlüğe sahip değildirler". ${ }^{35}$

Krause'nin tekillik ve özdeşlik arasında kurduğu bağıntıya dönecek olursak, yansımalı olmayan mantık sistemlerinin hangi gerekçelerle klasik mantığın özdeşlik ilkesinin kuantum parçacıklarını tanımlamada yetersiz olduğunu iddia ettiği daha anlaşılır kılınır. French ve Krause, "biz tekillik ve özdeşlik arasında güçlü bir ilişki olduğunu var sayıyoruz... Zira biz öz-kimlik/özözdeşlik bă̆ıntısının $a=$ a'nın anlamlı olmadığı bu varlıklar için 'tekil olmamayı tanımladık”36 der. Arenhart ise French ve Krause'nin bu görüşlerini şu şekilde aktarır:

31 Newton C. A. da Costa, Décio Krause, Schrödinger Logics, s.3.

32 Decio Krause, Quantum Mechanics, Ontology, and Non-Reflexive Logics, 2018, s.14.

33 Jonas R. Becker Arenhart, New logics for quantum non-individuals?, s.5.

34 A.e., s.5.

35 Jonas R. Becker Arenhart, New logics for quantum non-individuals?, s.6.

36 Akt: A.e., s.5. 


\begin{abstract}
Kuantum mekaniğinin metafiziği üzerine yapılan son tartışmalarda varılan sonuç bu varlıkların kesinlikle tekil olmayan [non-individuals] ve özdeşlik koşullarına sahip olmayan varlıklar olduklarıdır. Schrödinger mantığının geliştirilmesi yoluyla French ve Krause (2006) özdeşlikten yoksun olmakla tekil olmamayı ilişkilendiler ve yansımalı olmayan sistemlerin bu tür varlıklarla uğraşan formel sistemler olduklarını ifade ettiler. ${ }^{37}$
\end{abstract}

French ve Krause'ye göre asıl sorun, klasik mantığın yansımalı özdeşlik ilkesine sahip olması nedeniyle özgünlük üzerinden her şeye tekillik bahşetmesidir. Dolayısıyla klasik anlayışa göre her şey kendisine özdeştir, her şey bir birlik taşır ve tekildir. Bu makro dünyada dünyada uygulanabilir bir ilke olarak görülebilir. Ancak yansımalı olmayan mantıklara göre klasik mantık bu varsayımlarından dolayı mikro dünyada, kuantum parçacıkların tekillikleriyle ilgili konularda bir şey söylemede başarısızdır. Buradan hareketle yansımalı olmayan mantıklar özdeşlik bağıntısını kullanan formülleri sınırlandırarak tekillikleri ayırt edilemeyenleri, dolayısıyla da bazı hiçbir özgünlüğ̈̈ olmayan varlıklar ${ }^{38}$ açıklama problemini çözmeye girişmektedir. Sonuç olarak "yansımalı olmayan mantıklarda, özdeşlik ilkesinin başarısız olduğu ve böyle bir başarısızlıkla birlikte, geleneksel "Düşünmenin İlkelerinden" birinin evrensel olmadĭğ, zorunlu olmadiğg, a priori olmadı̆̆

\title{
Sonuç
}

Bu çalışmanın amacı klasik mantık anlayışının temel ilkelerinden biri olan özdeşlik ilkesinin hangi varsayımlara dayandığını göstermek ve bu varsayımlara karşı durarak oluşturulan mantıkları temel iddiaları çerçevesinde tanıtmaktı. Klasik mantık, makro evrene uygulanabilir ilkeler üzerinden oluşturulmuş ve bu ilkeler uzun yıllar boyunca işlev görmüşlerdir. Özellikle özdeşlik ilkesi ve ondan türetilebilen çelişmezlik ve üçüncü halin imkansızlığı ilkeleri öyle çok geçerli kabul edilmişlerdir ki, aklın veya düşünmenin temel ilkeleri olarak bilinegelmişlerdir. Özdeşlik ilkesi genel olarak her nesnenin kendisine özdeş, tekilliğe sahip ve ne kadar benzer olurlarsa olsunlar bir bakımdan diğer şeylerden ayırt edilebilir olduklarını varsayar. Hiçbir bakımdan ayırt edilemeyen nesneleri ise özdeş kabul ederek ayırt edilemezlerin özdeşliği ilkesini kabul eder. Oysa yansımalı olmayan mantıklar kuantum mekaniğinden hareketle özdeşlik ilkesinin ne var sayıldığı gibi her nesneye uygulanabildiğini ne de düşünmenin temel ilkeleri denecek kadar a priori ve evrensel bir ilke olduğunu iddia eder. Hatta böyle düşünmenin bazı alanlarda açıklama yapmanın önünde engeller oluşturduğunu ileri sürer. Bu mantık sistemlerinde ayırt edilemezlik ve özdeşlik arasında temel bir fark olduğunu, özdeşlik kavramında bir nesne söz konusuyken ayırt edilemezlikte iki nesnenin olabileceği iddiası öne sürülmektedir. Başka deyişle klasik özdeşlik ilkesinin aksine iki nesne ayırt edilemez olabilir ve buna rağmen özdeş olmayabilirler, yani yine de iki ayrı şey olabilirler. Bu ayırt edilemezlik ile özdeşlik arasındaki farkın fark edilmesiyle ilgilidir. Yansımalı olmayan mantıklar kuantum parçacıkların dolanıklığı ve bu nedenle de ayırt

37 Jonas R. Becker Arenhart, Newton da Costa On Non-Reflexive Logics and Identity, Brazil, s.3.

38 New logics for quantum non-individuals?, s.6.

39 Newton da Costa On Non-Reflexive Logics and Identity, s.3. 
edilemezlikleri üzerinden bir parçacığın hem sadece kendisi olamayacağı hem de bir diğer şeyden ayırt edilemediği halde o şeyle de özdeş kabul edilemeyeceğini söyler. Bu bakımdan yansımalı olmayan mantıkların temel ayrımları ayırt edilebilirlik-ayırt edilemezlik, tekillik-tekil olmayış ve özdeşlik-özdeşsizlik kavramları arasındadır. Bu kavramlar arasında bir ayrıma gidilmesinin temel sebebi ise kuantum dünyasında gözlemlenen dolanıklığı açıklama ihtiyacıdır.

Yansımalı olmayan mantıkları temellendirirken karşılaşılan asıl zorluk, özdeşliğin bizim için özellikle de konuştuğumuz, kullandığımız dilin temel bir bileşeni olmasıdır. Özdeşlik ilkesini reddetmemiz veya geçerli olmadığını söylememiz sadece kuantum nesnelerle ilgili bir yorumu ve durumu değiştirmez, ayrıca kullandığımız dilin ifade kaynaklarını da etkiler. Ayrıca özdeşliği hakkında konuşamadığımız şeylerin diğer şeylerden nasıl ayırt edileceği konusunda da güçlük yaşarız. Bu güçlük aynı zamanda, şeyler arasında bir ayrım yapma yolu olan niceleme sorununu doğurur. Başka deyişle niceleme sorunu, ayırt edilemeyen nesnelerin ölçümlerinin de belirsiz olmasina neden olur.

\section{Kaynaklar}

Arenhart, Jonas R. Becker. New logics for quantum non-individuals?.

Arenhart, Jonas R. Becker. Newton da Costa On Non-Reflexive Logics and Identity, Brazil.

Arenhart, Jonas R. Becker and Krause, Décio. Classical logic or non-reflexive logic? A case of semantic underdetermination, Publicado na Revista Portuguesa de Filosofia 68, 2012, ss.73-86.

Beziau, Jean-Yves. What is the principle of identity?, Logica e Flosofia da Logica, 2004.

Bueno, Otavio and da Costa, Newton C. A. Lodicas nao-reflexivas, 2009.

Burgess, John P. Philosophical logic, Princeton University Press, 2009.

da Costa, Newton C. A. and de Ronde, C. Non-Reflexive Logical Foundation for Quantum Mechanics, in Foundations of Physics, December 2014.

da Costa, Newton C. A. and Krause, Décio. An Intensional Scrödinger Logic, Notre Dame Journal of Formal

Logic Volume 38, Number 2, Spring 1997.

da Costa, Newton C. A. and Krause, Décio. Schrödinger Logics.

Fermüller, Chris. "Nonclassical logics", 2016/2017.

Haack, Susan. Deviant logic: some philosophical issues, Cambridge University Press, London, 1974.

Işıklı, Şevki. Kuantum Felsefesi Postmodern Bilimin Doğuşu, Ankara, Birleşik Yay., 2012.

Krause, Décio. Quantum Mechanics, Ontology, and Non-Reflexive Logics, 2018.

Krause, Décio. The Problem of Identity and a Justification for Non-Reflexive Quantum Mechanics, 2011.

Preskill, John. Quantum Computing and The Entanglement Frontier, Rapporteur talk at the 25th Solvay Conference on Physics “The Theory of the Quantum World” Brussels, 19-22 October 2011. 